\title{
CORRIGENDUM
}

\section{Prostate cancer risk related to foods, food groups, macronutrients and micronutrients derived from the UK Dietary Cohort Consortium food diaries}

JA Lane, SE Oliver, PN Appleby, MAH Lentjes, P Emmett, D Kuh, A Stephen, EJ Brunner, MJ Shipley, FC Hamdy, DE Neal, JL Donovan, K-T Khaw and TJ Key

European Journal of Clinical Nutrition (2017) 71, 567; doi:10.1038/ejcn.2017.17; published online 15 March 2017

Correction to: European Journal of Clinical Nutrition (2017) 71, 274-283; doi:10.1038/ejcn.2016.162; published online 28 September 2016

Updated online 15 March 2017: This article was originally published under a CC BY-NC-SA 4.0 license, but has now been made available under a CC BY 4.0 license. The PDF and HTML versions of the paper have been modified accordingly.
(C) (i) This work is licensed under a Creative Commons Attribution 4.0 International License. The images or other third party material in this article are included in the article's Creative Commons license, unless indicated otherwise in the credit line; if the material is not included under the Creative Commons license, users will need to obtain permission from the license holder to reproduce the material. To view a copy of this license, visit http://creativecommons.org/licenses/ by/4.0/

(c) The Author(s) 2017 